\title{
When the personal is international: implementation of the National Action Plan on resolutions 1325 and 1820 in Nepal
}

Punam Yadav

Gender, Technology and Development, https://doi.org/10.1080/09718524.2020.1766187

\begin{abstract}
This year, the United Nations Security Council Resolution 1325 is celebrating its 20th anniversary, which has brought renewed attention to the Women, Peace, and Security (WPS) agenda. Studies examining the progress made since the adoption of res. 1325 point to different challenges that still persist for its effective implementation. One of the main challenges is perceived to be the lack of commitments from local governments, especially with regard to resource allocation for implementation. Although a growing number of UN member states have adopted national action plans (NAPs) on res. 1325, only $34 \%$ of them have allocated budgets for their implementation. This study examines the implementation of one of the most praised NAPs, the Nepal NAP 2011. The study reveals that the effectiveness of the WPS agenda relies on many actors, not just the government. The role of international donors is equally crucial. In countries like Nepal, where a large portion of the development budget comes from international donors, giving sole responsibility for the implementation of the WPS agenda to the government limits its transformative potential and raises questions around the accountability of the international community.
\end{abstract}

\section{Keywords}

National Action Plan on Resolution 1325; Women; Peace and Security (WPS); UNSCR 1325; Women and War; Nepal 


\section{Introduction}

The United Nations Security Council Resolution 1325 (res. 1325 hereafter), the first resolution and the founding document of the Women, Peace, and Security (WPS) agenda, is celebrating its 20th anniversary this year. Res. 1325 recognizes the disproportionate impacts of conflict on women and girls in the changing war context (George \& Shepherd, 2016; True, 2016). ${ }^{\mathrm{i}}$ Res. 1325 is significant in many ways (Otto, 2016). For the first time in history, the door of the UN Security Council was open to women, and the security of women in conflict was discussed by the Security Council (Cohn et al., 2004). Res. 1325 is also significant because it was the outcome of decades of advocacy and transnational collaborations between women's rights advocates from around the world (Cockburn, 2007; Hill et al., 2003; True, 2016). Therefore, some consider res. 1325 as a watershed moment, which paved the way for incorporating gender perspectives into international peace and security legislations (Guerrina \& Wright, 2016).

Res. 1325 has four priority areas (also known as the pillars): the participation pillar calls for increased women's participation in decision-making; the protection pillar calls for the protection of women and girls from sexual and gender-based violence; the prevention pillar calls for the advancement of intervention strategies for the prevention of gender-based violence; and the relief and recovery pillar calls for improvements to relief and recovery in crisis situations which is responsive to gender specific needs. Nine additional resolutions have been adopted since res. 1325 , aiming to expand and strengthen the provisions of res. $1325 .{ }^{\text {ii }}$ Hence, the WPS agenda is made up of res. 1325 and nine subsequent resolutions (res. 1820 [2008]; res.1888 [2009]; res. 1889 [2010]; res. 1960 [2011]; res. 2106 [2013]; res. 2122 [2013]; res. 2242 [2015]; res. 2467 [2019]; and res. 2493 [2019]). 
Since its adoption in 2000, res. 1325 has attracted significant attention from policymakers, practitioners, and academics. The 20th anniversary of res. 1325 has brought renewed attention to the WPS agenda. However, studies examining the progress made since the adoption of res. 1325 point to different challenges that still persist in the implementation of the WPS resolutions. For instance, the Global Study, which was commissioned in 2015 by UN Women to examine the achievements of res. 1325 , suggests that despite some discursive shifts, the WPS agenda has had a very limited impact on the ground. The goals established at the normative levels have not been translated into the lives of people affected by conflict (UN Women, 2015, p. 268).Burgeoning scholarship in the field of WPS also points to various challenges for its implementation, with some questioning its ontological positioning, including the situatedness of the WPS agenda and its discursive construction, which has impact on the ground (Basu, 2016; Parashar, 2018; Shepherd, 2016). Others have highlighted the operational challenges, including the lack of funding, lack of local ownership, and so forth (Beoku-Betts, 2016; Ferris, 2018; Rayman et al., 2016).

Nepal was the first country in South Asia to adopt a NAP on res. 1325, which it did in 2011. Nepal's NAP was praised internationally because of its highly consultative process, with extraordinary levels of collaboration between the government, civil society, and nongovernmental organizations. Nepal also participated in the Global Study on 1325 in 2015. In this paper, I aim to examine the contrast between the supposed success of Nepal's NAP and its minimal impact on the ground. I argue that although the NAP received a significant amount of attention, both from the government and nongovernmental organizations, and although significant efforts were made to include the voices of local people, the NAP's achievements are very few considering the investment. Only a small number of people have benefited from the NAP. Instead of helping to improve the lives of women impacted by armed conflict, the 
NAP reduced the scope of the whole WPS agenda to a few projects. Despite its efforts at localization, it has remained an international project for three fundamental reasons: a) its Western centric approach, which assumes Nepal to be a 'global' norm recipient country (Basu, 2016), means reliance on the international community not only for funding but also for expert knowledge, ignoring local dynamics and putting the country right at the bottom of the power relations; b) convenience, which includes standardization and limited interpretation of conflict, ignores both other conflicts and complexities within each conflict, as well as volatile but dynamic local political landscapes (Horst, 2017; Parashar, 2018); and c) the lack of accountability of the international community to the WPS agenda despite their strong presence in conflict-affected countries. The main contribution of this paper is to enrich current understandings around the WPS agenda by bringing the subalterns' voices to inform the scholars and practitioners working in the field of WPS.

\section{The WPS agenda}

Although the legal status of the WPS resolutions and the extent to which the member states have to comply with these resolutions are subject to persistent debate, to show their commitment to the UNSC, the member states have adopted different mechanisms for the implementation of WPS resolutions. The most common strategy seems to be the development of NAPs (Jacevic, 2018; Shepherd, 2016; True, 2016). As of January 2020, 83 countries have developed NAPs. The most recent addition is Bangladesh, which adopted its NAP in November 2019. Eleven regional NAPs have also been adopted, such as the African Union NAP and the European Union NAP. An additional nine countries have shown commitments to developing their first NAPs ahead of the 20th anniversary of res. 1325, which suggests growing commitment toward the WPS agenda. ${ }^{\text {iii }}$ Although the content, focus, and process involved in 
developing a NAP have evolved since the first NAP was adopted by Denmark in 2005, NAPs can, broadly, be divided into two categories: outward-looking NAPs developed by donor countries such as Australia, the UK, and Norway, with an external focus to support countries emerging from conflicts, and inward-looking NAPs developed by countries emerging from conflict, such as Nepal, South Sudan, and Palestine, with the goal of implementing the WPS agenda in their own contexts (Basu, 2016; Desmidt \& Davis, 2019; Shepherd, 2016; Shwaku, 2017; True, 2016).

\section{Twenty years on - where do we stand?}

Studies show that despite its growing popularity, the implementation of the WPS agenda has been weak. To mark the 15th anniversary of res. 1325, UN Women launched a Global Study in 2015 to review its achievements. Over 60 member states participated in the study, and nongovernmental organizations, civil societies, and academics also provided their inputs to this study. The Global Study showed that some important normative changes had taken place since the adoption of res. 1325, such as the recognition of conflict-related sexual violence (CRSV) as a war crime and crime against humanity within the jurisprudence of the International Criminal Court, the appointment of a Special Representative to report on cases of sexual violence in conflict by the secretary-general, and the adoption of the General Recommendation 30 by the Convention on the Elimination of all Forms of Discrimination Against Women (CEDAW) Committee, which makes the provisions of res. 1325 legally binding to its signatories. ${ }^{\text {iv }}$ However, the Global Study also noted many challenges to the implementation of res. 1325, such as the lack of funding, low women's participation in decision making, and very few actual prosecutions of the perpetrators of CRSV. It also emphasized the need for gender mainstreaming within the UN and local governments (UN Women, 2015). Current statistics 
show that out of the 83 countries who have adopted NAPs, only $34 \%$ of them have allocated budgets for NAPs' implementation. ${ }^{\mathrm{v}}$

The emerging scholarship on the WPS agenda from different parts of the world also confirms the findings of the Global Study and sheds light on additional context specific challenges. For example, Lee-Koo (2016, p. 336) traces the difficulty in translating 'the global feminist ambitions that inspired UNSCR 1325 into practice in the Australian national context.' She argues that 'the Australian NAP has seen the dilution of UNSCR 1325's feminist underpinnings at two principal stages,' the NAP document itself and the implementation (LeeKoo, 2016, p. 337). She claims that the Australian NAP fails 'to include a strong oversight framework for monitoring and evaluation, reporting and governance, and funding and resourcing,' which 'has significantly weakened the capacity of the document to insist upon feminist outcomes' (Lee-Koo, 2016, p. 337).

Basini and Ryan (2016) examine the implementation of the NAP in Liberia and Sierra Leone. They argue that

despite NAPs being pushed as the main format to implement 1325 in post-conflict countries, they are not always the most appropriate method especially in states with weak internal institutions. They reflect too much of the international agenda in their underlying design, and even when their content includes local voices, the method of delivery is still in a bureaucratic and technocratic format (Basini \& Ryan, 2016, p. 400). 
Like Lee-Koo (2016), they argue that the implementation of NAPs in these locations has been impacted by 'a lack of capacity, a lack of will, a lack of funding and competition for scarce resources between government departments and agencies' (Basini \& Ryan, 2016, p. 400).

Some studies have suggested that the involvement of civil society organizations (CSOs) in the development and implementation of NAPs has the potential to increase their effectiveness. For example, Bjorkdahl and Selimovic (2018, p.1), by examining the role of CSOs in Bosnia, argue that 'women civil society organizations are key actors, as they not only set the agenda when it comes to WPS, they also play a key role in ensuring that the WPS principles are institutionalized and operationalized in policy.' However, studies from Sierra Leone, Liberia, and the Middle East suggest that, although the involvement of civil society has strengthened the relationship between the government and CSOs and has attracted some international funding, it has neither improved local ownership nor the lives of women in conflict and postconflict settings (Basini \& Ryan, 2016; Beoku-Betts, 2016; Rayman et al., 2016).

For some countries, the lack of local ownership has added further challenges to the implementation of NAPs (Beoku-Betts, 2016). For others, the problem lies with the approaches adopted for the implementation of the WPS agenda (Basini \& Ryan, 2016). Horst (2017) examines the status of the WPS agenda in Somalia. She argues that local realities are not considered when promoting gender equality agendas (Horst, 2017, p. 391). Motoyama (2018), analyzing the Japanese context asserts the NAP is just a showcase to display Japan's leadership on gender equality and peacebuilding without a real intention to make any difference. She argues,

the Japanese government, led by a leader with strong ties to historical revisionist and anti-feminist movements, has come to embrace Resolution 1325 in an attempt to 
identify itself as one of the powerful liberal democracies by advocating women's rights in the world, and to erase the memory of its own past military sexual violence... (Motoyama, 2018, p. 40).

Other studies point to how donor states have used the WPS agenda for their own benefit. Analyzing the case of Norway, Skjelsbaek and Tryggestad (2018, p. 10) argue that '[A]dvancing WPS in Norwegian foreign policy is the smart thing to do in its own right ... Being an active and visible norm entrepreneur on WPS is a way of gaining access, while also strengthening Norway's small state status in other issue areas.' Studies also suggest how the hypervisibility of CRSV reduces the scope and minimizes the transformative potential of WPS resolutions (True \& Hewitt, 2018; Basu \& Shepherd, 2017). Although the lack of commitment of the international financial institutions for human rights agendas have been brought to light by True and Svedberg (2018), the lack of accountability of international non-governmental organizations (INGOs) and donor organizations, who work with the local governments in countries emerging from conflict, is largely missing from the current WPS discourse. These organizations, which claim to be there to support local governments for peacebuilding, often with greater budgets, are outside the accountability framework of the local NAP.

Moreover, despite efforts to localize the WPS agenda, it remains international. This is evident not only on the ground but also in available scholarship. A bibliometric analysis of 321 articles published on the WPS agenda suggests that it is highly Anglo-centric, and perspectives from the 'Global South' or 'Third World' countries are missing (Palomo et al., 2017, p. 143). The outward-looking scholarship, which often focuses on content, language, or discourse, has not been very helpful in enhancing the WPS agenda in the Global South as it is far removed from reality (Cuillerier et al., 2017; Thomson, 2018; Trojanowska et al., 2018). Local voices are 
often absent in these analyses (Horst, 2017, p. 391), largely because of the lack of grounded research on the actual implementation of NAPs.

\section{Methodology}

Over the past 15 years, I have examined various gendered consequences of war on women, including the impacts of political quotas and the implementation of the WPS agenda in Nepal. This paper is based on my semi-structured interviews with 21 stakeholders involved in the development and implementation of the Nepal NAP, including government institutions, bilateral donors, UN agencies, INGOs, and CSOs. I have also interviewed four additional organizations that were working with conflict-affected people during and after conflict in Nepal, but they were not part of the NAP development or the implementation. The purpose of interviewing those organizations not involved in the NAP development process was to understand what they thought of the WPS agenda and its usefulness in Nepal. In order to understand the wider impacts of conflict on women, I have also conducted 60 interviews with women from various categories, including war widows (10), women IDPs (Internally Displaced People) (20), ex-combatants (5), and women politicians (25). The research participants were identified using purposing sampling. Each participant was given an information sheet which detailed the aim of the project and consent was sought from them prior to the interview. I have used pseudonym for my research participants to maintain their confidentiality.

This paper is also informed by my own lived experiences as a Nepali woman who has had firsthand experience of the war. Although the positionality of a researcher is highly contested in social science research because of the question of neutrality, I position myself within the 
interpretivist epistemology (Denzin, 1997), in which researchers are part of the research process, not a separate neutral entity. My knowledge of the local context, including an ability to speak the local language and an understanding of the culture, has helped me understand the complex socio-cultural nuances, which would otherwise have not been possible.

\section{The war context}

The civil war in Nepal, led by the Communist Party of Nepal (Maoists), lasted for 10 years (1996-2006), killing over 17,000 people; additionally, nearly 3,000 people disappeared (Office of the United Nations High Commissioner for Human Rights, 2012; Lawoti \& Pahari, 2010). People were injured and lost their livelihoods; schools were closed, and many public infrastructures, including police posts, health posts and bridges were destroyed. Women and girls suffered sexual violence from both sides of the conflict (Human Rights Watch, 2014). Those who were neutral feared both sides. Therefore, they left their villages for safer places, and most ended up in the capital city of Kathmandu (Yadav, 2016, 2020). Over 200,000 people were displaced during the ten years of war, and the majority of them were women and children (Caritas Nepal, 2005; IDMC, 2006). In addition, young people, who were at higher risk because they were targeted by both conflicting parties, migrated to other countries, posing challenges to those who were left behind in the rural villages, mostly women, the elderly, and children (Yadav, 2019). Even though some areas were hit harder than others, the impact of the war was felt by the whole nation. It has been 14 years since the People's War formally ended with the signing of a Comprehensive Peace Agreement (CPA) in 2006. According to the Kroc Peace Accord Matrix (2017), Nepal has successfully implemented $72 \%$ of the CPA. ${ }^{\mathrm{vi}}$ However, the reality is different. Thousands of people remain displaced (IDMC and NRC, 2011). Families of disappeared people are living in limbo without any knowledge of their loved ones (Trial 
International, 2016). Despite the hundreds of known cases of CRSV, no action has been taken to support the survivors (Ghimire, 2019). ${ }^{\mathrm{vi}}$

The Truth and Reconciliation Commission (TRC) was a promise of the CPA. However, it was only formally established in March 2016, a decade after the CPA was signed. The government also established another commission, the Commission of Investigation on Enforced Disappeared Persons (CIEDP), ${ }^{\text {viii }}$ to deal with the cases of disappearance. Combined, these commissions collected over 65,000 complaints in 2017 and 2018, including cases of CRSV, ${ }^{\text {ix }}$ but no progress has been made so far.Additionally, the Transitional Justice (TJ) mechanisms have been highly politicized, which has halted the whole TJ process. It is important to note that, by the time these commissions were established, the first NAP had already expired in February 2016.

Amidst these challenges, in April and May 2015, the country was hit by devastating earthquakes, which claimed over 9,000 lives and displaced millions of people. The priority of the government, as well as donors, shifted from conflict victims to earthquake victims; a similar shift occurred in Aceh, Indonesia, where post-tsunami recovery programs marginalized peace processes (Lee-Koo, 2012). Even though there is still a lot to be done to support the women impacted by the People's War, the government now believes that it has done enough and that there is no need for peacebuilding interventions, despite the fact that the TJ process has not been finalized. One of my respondents from an NGO who was involved in the NAP said, 'we can't talk about peacebuilding anymore. It is politically too sensitive' (Seema, July 2016). Similar responses were also shared by other organizations. Likewise, the external funding for peacebuilding has been significantly reduced. Despite overwhelming support for the first NAP, international donors are not keen on supporting the second NAP because either the WPS 
agenda is not their priority, and hence they will provide no funding for it, or they think it is the government's responsibility.

\section{Res. 1325: a new global gender norm?}

The WPS agenda is seen as a new 'global' gender norm, with the aim of passing it down to the local level to improve the status of women in conflict and post-conflict countries (Horst, 2017, p. 402). Hence, the Global South is seen as the norm recipient countries (Basu, 2016), which means that the knowledge of the WPS agenda lies in the hands of 'experts' from the Global North who need to train people from the Global South. In this section, I will discuss the localization of this new global gender norm in Nepal.

Res. 1325 was a new phenomenon in Nepal introduced by 'the WPS club.' The members of the WPS club included UN agencies, bi-lateral donors, international NGOs (known as development partners), and selected women's rights NGOs. The development partners in Nepal had the money and the mandate, and the local NGOs brought the 'authenticity' to the team for the localization of res. 1325. Although res. 1325 was adopted by the UNSC in 2000, when Nepal was in the middle of the civil war, most people, including government officials, did not know about it until 2007. The first ever meeting on res. 1325 was organized by some local NGOs, and outside experts were asked to explain what res. 1325 was to Nepalese stakeholders. Hence, the first knowledge about and interpretation of res. 1325 came from the Global North.

The first meeting was followed by a series of meetings in which strategies were discussed on how to implement res. 1325 in Nepal. Initially, the WPS club approached the Ministry for 
Women, Children, and Social Welfare (MoWCSW) because it was related to women. However, they later decided to approach the newly established Ministry of Peace and Reconstruction (MoPR). One of my respondents who was facilitating these negotiations said,

It was our strategic decision. If we went to the MoWCSW, it will become a women's project, and no one will take it seriously. Therefore, we decided to approach MoPR to have a better status and recognition (Sangita, Program Coordinator, July 2016).

The MoPR was a new ministry, established in 2007 , with the aim of building peace in the country, which seemed to be the perfect institution for res. 1325. The MoPR was very supportive of the WPS agenda, not only because it was a peacebuilding agenda but also because it received a strong support from international donors and civil society. Although the consultations with the MoPR started soon after it was established in 2007, discussions concerning the implementation of res. 1325 only started after the formation of a high-level steering committee in September 2009. This committee was chaired by the then-Deputy Prime Minister and co-chaired by the head of MoPR, both men. However, up until this time, no one knew about the NAP. It was only in 2010, when the discussion around marking the tenth anniversary of res. 1325 started, that they came to know about it and decided to pursue that route (Yadav, 2017a). Hence, the Nepal NAP was what True called a 'period effect,' suggesting that 'member states perceived the importance of WPS issues in light of the global meeting reviewing progress made over a decade in implementing $1325^{\prime}$ (2016, p. 312).

The first NAP planning meeting was held on 31 March 2010, and the Joint Secretary of the MoPR, representatives from different ministries, representatives from the development partners (including selected NGOs/CSOs), as well as the Peace Support Working Group 
(PSWG), were present. The PSWG is a consortium of multi-lateral and bi-lateral donors and UN agencies working together for the implementation of res. 1325 and 1820 in Nepal. The PSWG was chaired by the Norwegian Embassy and co-chaired by the United Nations Population Fund. This first planning meeting formed a technical committee to oversee the NAP drafting process. The technical committee had representatives from the MoPR, selected NGOs, and the PSWG. Meetings at various levels were held with the participation of senior government officials, including the Deputy Prime Minister and ministers from different ministries, as well as representatives from NGOs/CSOs, INGOs, UN agencies, and donors. To ensure that local concerns were incorporated, 52 district-level consultation workshops were held, facilitated by the government and the members of the WPS club. Three thousand people took part in these consultations, and 1,500 action points were drawn up (MoPR \& 1325 Action Group Nepal, 2014; MoPR, 2011). Expert support was sought from outside Nepal to design and refine the indicators, such as the Global Network of Women Peacebuilders (GNWP).

After a year of consultation and development, the first NAP on res. 1325 and 1820 was finally endorsed on 1 February 2011, making Nepal the first South Asian country to have a NAP on res. 1325. To celebrate this, government and some members of the WPS club went to New York for an international launch of the NAP during the $55^{\text {th }}$ Commission on the Status of Women in February 2011 (Saferworld, 2012). ${ }^{\mathrm{x}}$ This shows that although the government facilitated the development of the NAP, the WPS club in Nepal was the key player. The main goal of the Nepal NAP was 'to achieve sustainable peace and just society' by ensuring 'proportional and meaningful participation of women at all levels of conflict transformation and peacebuilding processes; and protection of women's and girls' rights' (MoPR, 2011, p. 24). It included a comprehensive log-frame with specific objectives, actions to be taken, 
expected results, indicators, implementing agencies, and a time frame (MoPR, 2011). It was an ambitious plan. However, the implementation of the NAP was a challenge.

A government official from the MoPR said, 'there was no implementation plan or dedicated funding. Therefore, the implementation was haphazard' (Bharat, July 2016). The Nepal Peace Trust Fund (NPTF), ${ }^{\mathrm{xi}}$ a collective fund of the government and donors, was established in 2007 to support the peacebuilding process in Nepal. For the implementation of the NAP, the NPTF allocated USD 7.2 million. The MoPR was not a line ministry, so it had to rely on other ministries for the implementation of its program. The official from the MoPR further added,

We asked ten line ministries to submit their proposals to implement NAP. The funding proposals were submitted for whatever they thought was relevant, without any needs assessments or coordination between the ministries on who was doing what. Therefore, similar projects got funded (Bharat, July 2016).

It shows the NAP was a box ticking exercise rather than a well thought out intervention. Most of the NPTF funding went to the Ministry of Defense (61\%), with less than $40 \%$ to other ministries, such as the Ministry of Education (10\%), the Small Cottage Ministry (7\%), MoWCSW (7\%), and less than 5\% to the National Women's Commission and other ministries (MoPR \& 1325 Action Group Nepal, 2014). In addition to these ten projects, the WPS club implemented their own projects on the NAP. However, this was neither known to the government nor part of the NAP monitoring mechanism (MoPR \& 1325 Action Group Nepal, 2014). They were 'goodwill projects' (additional support), funded solely by the international donors. Hence, they were accountable to the donors, not to the government. These NAP projects were small scale, short-term projects, ranging from one to three years. They mostly 
focused on awareness-raising, training, and capacity-building (MoPR, 2016). For instance, the International Labor Organization worked only in 13 villages and two municipalities of three districts, Kavre, Ramechap, and Sindhuli. According to the mid-term review report, this program benefited only 796 conflict-affected women (MoPR \& 1325 Action Group Nepal, 2014). Likewise, UN Women implemented the Strengthening Implementation of the Women, Peace, and Security Agenda in Nepal project funded by the government of Finland. This project was implemented only in three districts, Bajhang, Doti, and Kailali, to strengthen local implementation of the NAP (Search for Common Ground, 2016).

Moreover, the NAP was a project of only a few organizations. The organizations who were not involved in the development of the NAP or were not the implementing partners did not take the ownership or the responsibility of implementing the NAP. They criticized the approach taken by the WPS club. A respondent from an NGO who was not part of the NAP said, The res. 1325 is a project of some elite organizations. We are not part of it and not many people on the ground know about it (Kabita, Program Director, July 2016). Another respondent said, 'many people didn't know about 1325, even the government officials who were meant to implement it' (Minita, Program Manager, July 2016). Hence, although the NAP development process was remarkable, the NAP ended up being an end goal in itself.

The WPS agenda, which came to Nepal as an international gender norm, remained international. All of my research participants said that res. 1325 can be a useful framework if it is used to transform the lives of women. However, they also said that people cannot relate to it because it does not feel real to them. One of my research participants said, 'even if you give them training, they will remember for a few days and then forget' (Namita, Program Officer, July 2016). The program coordinator of an international NGO said, 'When I went into the field 
in the past, women knew what 1325 was but now they all have forgotten' (Sangita, July 2016). Therefore, the suggestion was that, instead of giving trainings on what the UNSC and what res. 1325 are, it would be easier for people to relate to them if we talk about the special needs of women in conflict and what needs to be done.

\section{Convenience - limited interpretation of conflict and its impacts}

The WPS agenda is a complex project that aims to address structural causes of violence. Therefore, it needs careful consideration and in-depth analysis of the local context before the development of any intervention, including a NAP. However, I argue, in reality, that does not happen. Shortcuts are applied, limiting the scope of the WPS agenda. The consultations happen, but they often do not reach the people affected on the ground. The consultations for identifying the impacts of conflict in Nepal took place outside the capital city, Kathmandu. However, they only reached the district headquarters, where district heads and local leaders participated (MoPR \& 1325 Action Group Nepal, 2014).

Moreover, the interpretation of the WPS agenda is limited. The standardization, where international principles of such global norms have to be incorporated, limits the scope and the transformative potential of the WPS agenda. Shepherd (2016, p. 3) underlines the problem of effectively implementing the WPS agenda at two levels: orientation and expertise. She argues that the limited interpretation of WPS principles reinforced by the understanding of war and insecurity 'overseas' leads to a perception that these countries are experts in WPS. This limits the applicability of the WPS agenda to internationally recognized wars (Shepherd, 2016, p. 3). In Nepal, only the Maoist conflict is recognized in the WPS discourse. The ethnic conflicts that erupted soon after the peace agreement, which caused further killings and displacements, are 
not. This meant that any support available through the Nepal NAP was only available to those affected by the Maoist conflict, marginalizing the victims of other conflicts.

Likewise, the limited interpretation of the impacts of conflict within the WPS discourse also has shaped its implementation. Only a certain type of issues, those which have 'international resonance,' are included, and others are ignored. For instance, issues such as increasing women's participation, the protection of women and girls, and CRSV form a big part of the WPS discourse. In addition, local politics, which could sexual violence. Therefore, no one wants to talk about it. (Sabita, Director, July 2016). Both, the security forces and the Maoists, were involved in committing this crime. Therefore, there was no willingness from the government to address it. The scope and the interpretation of the WPS agenda is also determined by the local actors, civil society organizations and the advocates of the WPS agenda due to their own political interests.

\section{The long term gendered impacts of war are left out from the WPS discourse}

When the conflict escalated and the country announced a state of emergency in 2002, many young people left their villages due to the fear of being caught in war. Samita was only 13 years old when she fled her village in search of a safer place, but she ended up in prostitution. She said, 'Many of my friends from my village had joined the Maoists. I didn't want to, so I fled and came to Kathmandu. I looked for work but without [a] certificate and any paperwork, I couldn't find a decent job. Therefore, I ended up here' (Samita, IDP and cabin restaurant worker, December 2016). Cabin restaurants, dance bars, and massage parlors, known as the entertainment sector, mushroomed in Kathmandu during the war (Yadav, 2017b). An estimated 
50-100 thousand people are currently working in this sector. A study by UNHCR and UNAIDs (2016, p. 39) revealed that $19 \%$ of the female sex workers in the study were forced into sex work due to conflict and displacement. The study also claims that forty three percent of their respondents knew of conflict victims who were pushed into sex work and $71 \%$ believed that the conflict had increased the number of female sex workers. Another respondent who also left her home during the conflict said,

When I came to Kathmandu, I needed to survive. It was risky to disclose my identity as I had come from a Maoist stronghold area ... I was scared of the security forces ... This was the easiest job I could find. They did not ask for any qualification or identity documents. Many girls coming from conflict affected areas joined this sector because they had no other alternative for survival (Reshma, IDP and cabin restaurant worker, January 2017).

Because they did not have any documents with them or proper academic qualifications, many of these displaced women and girls ended up in the entertainment industry. Bina, who was displaced during the conflict, now runs an NGO to support women and girls in the entertainment sector. Her organization has over 500 members, many of whom were displaced by conflict. She said, 'they never received any support as the victims of conflict or IDPs' (Bina, IDP and Chairperson of an NGO, January 2017). They are seen as bad women or prostitutes, in spite of what job or task they had done. Bina said that her organization provides awarenessraising and capacity-building trainings for these women and girls, such as trainings on HIV/AIDs and self-defense, and language training to better prepare them for their jobs. None of these IDP women knew anything about res. 1325. When I asked her if she knew about res. 
1325 , she said, 'I was asked to attend a training by one NGO ... I think it was on 1325 but I can't remember the details' (Bina, IDP and Chairperson of an NGO, January 2017).

The training on res. 1325 meant nothing for her, as it did not help her or the members of her organization who were displaced due to the conflict. Ferris (2018) also points to the similar experiences of Syrian IDPs. She argues, 'The fact that most of the refugees are not living in camps means that they are often "invisible" to both national authorities and international agencies' (Ferris, 2018, p. 9). Those who fall outside the 'internationally defined categories of victims' fall outside of the WPS discourse. Moreover, due to the stigma surrounding IDPs during the heightened conflict (they were seen either as Maoists or as corrupt people) and due to the fear of being caught by either of the conflicting parties, the displaced people did not want to disclose their identities. One of my respondents, who was a wife of a disappeared person, said she had to move to a new house several times because as soon as their landlords knew about who she was, she was asked to leave. She added, 'they [neighbors] wouldn't even let my children play with their children' (Ranjana, IDP, May 2012).

Because of the limited interpretation of the impacts of conflict and convenience of the actors involved in implementing it, the WPS agenda has failed to implement its own basic feminist principles. Tara was displaced due to not being accepted by her own family after she was raped. She said,

I was arrested on suspicion of being a Maoist. They [army] kept me in custody for five days for no reasons. They tortured me and sexually abused me every day. They released me after five days. Later I found out that I was pregnant. I was unmarried so my parents said I should leave the village because if people came to know about the pregnancy, 
that will damage the family reputation. I left home and came to Kathmandu. I have been here since then (Tara, December 2016).

She was an IDP, a survivor of CRSV and a victim of gender-based violence. However, she never received any support from anyone and had no idea about what res. 1325 was. Moreover, psycho-social support, which requires time and effort, often falls outside of the WPS discourse. Rita's husband was taken from home by the security forces. She has not seen him since then. She said,

I have been psychologically traumatized because of all the stress I have been through since his disappearance. There is no one to support me. My parents-in-law didn't give me anything [property], saying I was still young so I might elope with someone else. I have not rested since my husband disappeared. My days go by visiting various human rights organizations and the disappearance commission with the hope of finding some clue about my husband's whereabouts. I am very tired (Rita, wife of a disappeared person, December 2018).

In Nepal, the investigation on conflict related disappearance and support for their family members were seen as part of the transitional process to be dealt by the CIEDP, not as part of the WPS agenda.

The general conception that the problem (war) is out there is also seen at the local level. In Nepal, despite the country having a large number of conflict victims, including an overwhelming number of IDPs in Kathmandu, all of the NAP projects were implemented outside of Kathmandu. This also meant that those who fled the war and came to Kathmandu 
looking for a safer place, such as single mothers, families of disappeared people, and those who were forced to work as sex workers for survival after being displaced, never received any support.

Lastly, the pre-defined understanding of the post-conflict countries has an impact on the implementation of the WPS agenda. Post-conflict space is often seen as static in the international peace and conflict discourse. Nepal became a federal state after the new constitution was adopted in September 2015, before the first Nepal NAP expired. However, the WPS agenda in Nepal did not consider the dynamic and self-evolving political context. The MoPR has now been dissolved. There is a small unit in the Ministry of Home Affairs called Peace Promotion Section to oversee peace related matters with a much reduced scope, which means that the WPS agenda in Nepal has lost its institutional home. ${ }^{\text {ii }}$ The government officials who were supportive of the WPS agenda have now been transferred to other departments and those from outside of the government, who advocated for the implementation of the WPS and spent a lot of time building that support system within the government, have lost their contacts. There is a new governance structure in Nepal. There are three levels of independent government: the local government, the provincial government, and the federal government. Most of the officials at these three levels of government were not part of the NAP. Hence, if the WPS agenda is brought back to the table, it will then be a new beginning and require a completely different approach.

\section{When the personal is international}


Nepal is an aid-dependent country. Although there has been a decline in dependence on foreign aid since the 1950s, from $100 \%$ foreign funding for the first development plan of Nepal (19561960) to $75 \%$ of the development budget in the 1980 s, foreign aid still comprises much of the national budget (Karkee \& Comfort, 2016; Ministry of Finance, 2017; Shrestha, 2018). In a year, on average, $25 \%$ of the government's total budget comes from foreign aid (Ministry of Finance, 2017). Foreign aid increases in response to conflict and disaster. For instance, foreign aid to Nepal increased significantly after the peace agreement was signed in 2006 and after the 2015 earthquake (Ministry of Finance, 2018). ${ }^{\text {xii }}$

Moreover, NGOs play a key role in the development of Nepal. Although NGOs have been present in Nepal since the 1950s, their presence increased dramatically after the establishment of democracy in 1990, from 56 in 1990 to 46,235 by July 2017. ${ }^{\text {xiv }}$ Likewise, Nepal, even though it is a small country, has a large presence of INGOs. As of 2016, there were 254 INGOs in Nepal, with headquarters in the United States (53), the UK (25), Germany (12), Switzerland (11), and Japan (11). ${ }^{\mathrm{xv}}$ Some of these INGOs have worked in Nepal for several decades. Despite their significant presence and decades of involvement in development programs, neither NGOs nor INGOs receive funding from the Nepal's government. They rely solely on foreign funding (Onta \& Bhandari, 2018), which also means that their development agendas are guided by the donors' priorities.

Likewise, CSOs have played an important role in Nepal, especially in advancing the rights of women and marginalized groups. In Nepal, rights-orientated NGOs are seen as CSOs, especially those working on women's rights and the rights of marginalized people. Yet most of these CSOs cannot sustain themselves without foreign funding. They operate like NGOs, taking on many projects. Hence, none of these CSOs has been able to fully commit to the WPS 
agenda due to a lack of funding, despite their active involvement in the development of the first Nepal NAP. In my interviews, some of the NGOs involved in the development of the first NAP said that despite their willingness, they have not been able to do anything because there is no funding for the WPS agenda. Many NGOs that were actively involved in the advocacy and implementation of res. 1325 are now doing other projects, such as building resilience after the 2015 earthquake. In part that is because where the money is, as donors shifted their priorities from peacebuilding to reconstruction and resilience- building post-earthquake in 2015. For example, although a considerable number of conflict-related grievances need to be addressed and Nepal needs support from the international community, Nepal is no longer a 'WPS focus country' for the UK. The third UK NAP identifies nine countries as priorities, ${ }^{x v i}$ excluding Nepal. This also means that there is no funding for res. 1325 and that no reporting on the progress of the WPS agenda is required. Similar responses were shared by other donor agencies and INGOs who were heavily involved in the development of the first NAP but showed no interest in supporting the second NAP.

Moreover, Nepal relies heavily on foreign aid for its development activities. A large part of the total yearly budget is recurrent expenses $(62.8 \%)$, and another quarter (26.2\%) is capital budget, which is spent mostly on civil projects and building structures (Sapkota, 2017), which means that only a small percentage remains for additional activities. Ten years of civil war, ongoing ethnic conflicts, and regular environmental hazards further stretched the budget. Therefore, the government called for international support to rebuild the nation after the CPA in 2006. The international support received for reconstruction and peacebuilding was less than what the government had asked for. Hence, despite its willingness and commitment, the government could not allocate additional funding for the NAP, except for ten NPTF-funded projects. ${ }^{x i i}$ Nonetheless, the government created all the necessary structures for the 
implementation of the NAP, from the national to the local levels, even though there was no funding to run these organizations effectively. This is not to claim that there were no challenges from the government side - political instability, frequent transfer of government officials, and limited knowledge of the WPS agenda among duty-bearers were some of the challenges. However, it is important to note that these challenges were not entirely new. This was the context in which the first Nepal NAP was developed.

Moreover, it is important to note that international organizations play an important role in Nepal. In 2017-2018 alone, the foreign funding received by the INGOs in Nepal exceeded the foreign aid that the government of Nepal received in the same year (Shrestha, 2018). The international organizations implemented a large number of development projects, including WPS projects, which were independent of the government's projects. These independent projects were neither part of the government's monitoring mechanisms nor did they have any accountability to the government. A respondent from an NGO who was actively involved in the development and the implementation of the Nepal NAP said, "whoever could bring the money implemented projects on $1325^{\prime}$ (Kashi, Program Coordinator, July 2016). A government official said,

We had no knowledge of who was doing what. The development partners were doing their own projects on NAP, which we couldn't track (Bharat, July 2016).

The mid-term review of the first NAP confirms this, which points to the difficulty of measuring the achievements of the NAP because the projects implemented by international donors were not part of the monitoring mechanism (MoPR \& 1325 Action Group Nepal, 2014). The dependency of the international organizations on foreign funding and the voluntary nature of 
their intervention also means that, despite their heavy presence in Nepal both during conflict and in post-conflict, they were not accountable to the WPS agenda. Hence, the implementation of the Nepal NAP became the sole responsibility of the government. It could be argued that this is one of the reasons for the failure of the first Nepal NAP.

The global slashing of foreign aid also had an impact on the WPS agenda in Nepal. A senior officer from an international NGO said,

There is no dedicated fund for the WPS agenda. When there is a funding cut, soft issues like this suffer. We can't cut funds from our ongoing projects ... it is difficult to cut funding from infrastructure projects (Pabitra, July 2016).

She further added, 'the WPS [agenda] is a long-term plan and needs a long-term investment. Therefore, it should be the government's responsibility' (Pabitra, July 2016). Despite support from international donors, the WPS agenda became, as argued by Kirby and Shepherd (2016, p. 383), the state's responsibility, and for the WPS club, implementation of the NAP was a choice. The involvement of civil society organizations, as argued by Kirby and Shepherd (2016, p. 384), did help bring some people's concerns into the NAP; however, it did not lead to local ownership.

The first Nepal NAP expired in February 2016. As of February 2020, there has been no sign of a second NAP. The government and the advocates of the WPS agenda in Nepal are still seeking international support without success. Hence, although local ownership is crucial for the sustainability of the WPS agenda, the accountability of the international community cannot be overlooked, especially in fragile states like Nepal. Organizations working in countries 
emerging from conflict should have the same responsibility and accountability toward implementing the local NAP as the local government and they should be part of integrated monitoring and evaluation processes.

\section{Conclusion}

In this paper, I have analyzed the effectiveness of the first Nepal NAP, which shows that even a well-articulated policy, developed by the WPS experts, could not make much difference to the lives of women impacted by conflict. I have discussed some of the key challenges to its implementation in this paper. Its Western-centric approach, which relied on outsiders not just for funding but also for knowledge and expertise, shaped the local WPS discourse, reducing the scope of the WPS agenda to only internationally recognized wars (Shephard, 2016). The limited interpretation of the war meant that only the Maoist conflict was recognized in the Nepal NAP, and other ethnic conflicts, which started soon after the peace agreement, resulting in further killings and displacements, were ignored. Hence, the majority of the people impacted by various conflicts were left out of the Nepal NAP.

Moreover, the Nepal NAP only recognized certain issues that had international resonance, making many gendered impacts invisible. For instance, the IDPs, who were forced to enter prostitution due to the situations created by conflict, were left out of the NAP. This study also suggests that the scope of the WPS agenda further gets reduced due to the local politics. For instance, the CRSV was absent from the first NAP due to being politically too sensitive. Although the involvement of civil society has some benefits, this study also confirms, as Basini and Ryan (2016) have argued, that the involvement of CSOs does not lead to local ownership, 
nor does it improve the lives of women impacted by the conflict. This study also confirms that the location of NAP is important and going to a high-profile ministry could bring more attention to the WPS agenda (Swaine, 2009). However, it requires further research and strategic thinking with a long term vision.

The MoPR did bring some attention to the WPS agenda in Nepal. However, it was not a good location for the Nepal NAP because the MoPR was not a line ministry. It had to rely on other ministries for the implementation of the NAP at the local level. The MoPR was established with a mandate for building peace. It has now been dissolved and the WPS agenda in Nepal has lost its institutional home. Moreover, the WPS agenda sees post conflict space as static, not a dynamic political landscape. Nepal is now a federal state, with three levels of governments. The WPS agenda in Nepal now needs a completely new approach, if it is to be brought back in the future. Moreover, Nepal's failure to effectively implement the NAP is not uncommon. Most countries in conflict or emerging from conflict have scarce resources and weak institutional structures (Barrow, 2016; Basini \& Ryan, 2016). Therefore, the political will of the government is not enough for the effective implementation of the WPS agenda. It requires a much more comprehensive and holistic approach. Hence, instead of giving the sole responsibility of the implementation to the government, it is necessary to bring all actors, including I/NGOs, UN agencies, bilateral and multilateral organizations, working in conflict affected countries, into the accountability framework of the local NAP.

Finally, although the past two decades have seen a rapid growth of the WPS literature, there is still an absence of local voices and thus local perspectives are missing from the WPS scholarship (Horst, 2017). The studies on actual implementation of the WPS agenda are still very limited. Outward looking scholarship, studies carried out by the scholars from the Global 
North, for the people of the Global South, have not been very helpful as they do not reflect the local reality (Cuillerier et al., 2017; Thomson, 2019). Therefore, the future WPS scholarship should focus on more grounded research that involves speaking to people impacted by the war, understanding the local dynamics and producing knowledge that is relevant and useful to the people on the ground. In other words, more grounded research is required to better understand the local realities, the usefulness of the WPS resolutions and challenges to their implementation.

\section{References}

Barrow, A. (2016). Operationalizing Security Council Resolution 1325: The role of national action plans. Journal of Conflict and Security Law, 21(2), 247-275.

https://doi.org/10.1093/jcsl/krw002

Basini, H., \& Ryan, C. (2016). National action plans as an obstacle to meaningful local ownership of UNSCR 1325 in Liberia and Sierra Leone. International Political Science Review, 37(3), 390-403. https://doi.org/10.1177/0192512116636121

Basu, S. (2016). The Global South writes 1325 (too). International Political Science Review, 37(3), 362-374. https://doi.org/10.1177/0192512116642616

Basu, S., \& Shepherd, L. J. (2017). Prevention in pieces: Representing conflict in the women, peace and security agenda. Journal of Global Affairs, 3(4-5), 441-453.

https://doi.org/10.1080/ 23340460.2017.1415723

Beoku-Betts, J. (2016). Holding African states to task on gender and violence: Domesticating UNSCR 1325 in the Sierra Leone National Action Plan. Current Sociology, 64(4), 654-617. https://doi.org/10.1177/0011392116640459 
Bjorkdahl, A., \& Selimovic, J. M. (2018). WPS and civil society. In S. E. Davies and J. True (Eds.), The Oxford handbook of women, peace, and security (pp. 1-13). Oxford University Press.

Caritas Nepal (2005). Caravan of conflict: A study of dynamics of conflict-induced displacement in Nepal. Caritas Nepal.

Cockburn, C. (2007). From where we stand: War, women's activism and feminist analysis. Zed.

Cohn, C., Kinsella, H., \& Gibbings, S. (2004). Women, peace and Security Resolution 1325. International Feminist Journal of Politics, 6(1), 130-140. https://doi.org/10.1080/ 1461674032000165969

Cuillerier, M., Sarosi, D., St-Pierre, K. (2017). What's in a NAP? A short analysis of selected women, peace \& security national action plans. https://wpsncanada.files.wordpress.com/2017/01/shortanalysis-paper-wpsn-c-final-2017.pdf

Denzin, N. (1997). Interpretive ethnography: Ethnographic practices for the 21 st century. Sage.

Desmidt, S., Davis, L. (2019). Rhetoric and real progress on the Women, Peace and Security agenda in Africa, ECDPM Discussion paper No. 245. https://ecdpm.org/wp-content/uploads/ ECDPM-DP245-Rhetoric-progress-Women-Peace-and-Security-agenda-Africa-March2019.pdf

Ferris, E. (2018). Protecting displaced women and girls: The case of Syria. In S. E. Davies and J. True (Eds.), The Oxford handbook of women, peace, and security (pp. 1-17). Oxford University Press. 
George, N., \& Shepherd, L. J. (2016). Women, peace and security: Exploring the implementation and integration of UNSCR 1325. International Political Science Review, 37(3), 297-306. https://doi.org/10.1177/0192512116636659

Ghimire, B. (2019, June 20). Nepal yet to take steps to ensure justice for women who suffered sexual violence during conflict. http://kathmandupost.ekantipur.com/news/2019-0620/nepalyet-to-take-steps-to-ensure-justice-for-women-who-suffered-sexual-violence-duringconflict.html?fbclid=IwAR29O5WKgqwdq6-AreoGzTwSi4TwqWAYTum7_trqzCAo7Esz1Ruq4fwMtA

Guerrina, R., \& Wright, K. A. M. (2016). Gendering normative power Europe: lessons of the women, peace and security agenda. International Affairs, 92(2), 293-313. https://doi.org/10. $1111 / 1468-2346.12555$

Hill, F., Aboitiz, M., \& Poehlman-Doumbouya, S. (2003). Nongovernmental organizations' role in the buildup and implementation of Security Council Resolution 1325. Signs: Journal of Women in Culture and Society, 28(4), 1255-1269. https://doi.org/10.1086/368321 Horst, C. (2017). Implementing the women, peace and security agenda? Somali debates on women's public roles and political participation. Journal of Eastern African Studies, 11(3), 389-407. https://doi.org/10.1080/17531055.2017.1348000

Human Rights Watch. (2014). Silenced and forgotten: Survivors of Nepal's conflict-era sexual violence. https://www.hrw.org/report/2014/09/23/silenced-and-forgotten/survivorsnepals-conflict-era-sexual-violence International Displacement Monitoring Centre and Norwegian Refugee Council. (2011). Nepal:

Failed implementation of IDP policy leaves many unassisted: A profile of the internal displacement situation. http://www.refworld.org/pdfid/4b61a32f2.pdf 
International Displacement Monitoring Centre. (2006). Nepal: IDP return still a trickle despite ceasefire. Norwegian Refugee Council.

Jacevic, M. M. (2018). WPS, states, and the national action plans. In S. E. Davies and J. True (Eds.), The Oxford handbook of women, peace, and security (pp. 1-20). Oxford University Press.

Karkee, R., \& Comfort, J. (2016). NGOs, foreign aid, and development in Nepal. Frontiers in Public Health, 4(177), 177-175. https://doi.org/10.3389/fpubh.2016.00177

Kirby, P., \& Shepherd, L. J. (2016). The futures past of the women, peace and security agenda.

International Affairs, 92(2), 373-392. https://doi.org/10.1111/1468-2346.12549

Lawoti, M., \& Pahari, A.K. (Eds.). (2010). The Maoist insurgency in Nepal: Revolution in the twentyfirst century. Routledge.

Lee-Koo, K. (2012). Gender at the crossroad of conflict: Tsunami and peace in post-2005 Aceh. Feminist Review, 101(1), 59-77. https://doi.org/10.1057/fr.2011.54

Lee-Koo, K. (2016). Engaging UNSCR 1325 through Australia's national action plan. International Political Science Review, 37(3), 336-349. https://doi.org/10.1177/0192512116629821

Ministry of Finance. (2017). A study on foreign aid mobilisation in federal Nepal. http://www.mof.gov.np/uploads/document/file/20171231154550.pdf Ministry of Finance. (2018). Budget speech of fiscal year 2018-2019. http://mof.gov.np/uploads/document/file/speech_english_20180715091522.pdf Ministry of Peace and Reconstruction and 1325 Action Group Nepal. (2014). Mid-term monitoring report of the National Action Plan on the Implementation of United Nations Security Council Resolutions 1325 and 1820 (2011-2016). https://saathi.org.np/wpcontent/uploads/2018/10/saathimidtermreportenglish.pdf 
Ministry of Peace and Reconstruction. (2011). National Action Plan on the Implementation of United Nations Security Council Resolutions 1325 and 1820 (2011-2016).

http://www.kpsrl.org/uploads/debatten_discussies/nepals_national_plan_of_action_english.p df

Ministry of Peace and Reconstruction. (2016). Nepal peace trust fund progress report 27. http://www.nptf.gov.np/uploads/files/27\%20th\%20Progress\%20Report\%2014\%20March\%2 02016\%2015\%20July\%202016.pdf

Motoyama, H. (2018). Formulating Japan's UNSCR 1325 national action plan and forgetting the "comfort women. International Feminist Journal of Politics, 20(1), 39-53. https://doi.org/10.1080/14616742.2017.1413582

Office of the United Nations High Commissioner for Human Rights. (2012). Nepal conflict report:An analysis of conflict-related violations of international human rights law and internationalhumanitarian law between February 1996 and 21 November 2006. https://www.ohchr.org/Documents/Countries/NP/OHCHR_Nepal_Conflict_Report2012.pdf Onta, P., Bhandari, A. (2018). Why Nepali NGOs have to rely on foreign funds. http://www.martinchautari.org.np/index.php/71-chautarian-speak/697-why-nepali-ngos-haveto-rely-on-foreign-funds-by-pratyoush-onta-and-avash-bhandari

Otto, D. (2016). Women, peace and security: A critical analysis of the Security Council's vision. LSE Women, Peace, and Security Working Paper Series, 1, 1-10. http://www.lse.ac.uk/WomenPeaceSecurity/pdf/2016/wps1Otto.pdf Palomo, J., Figueroa-Domecq, C., \& Laguna, P. (2017). Women, peace and security state-ofart: A bibliometric analysis in social sciences based on SCOPUS database. Scientometrics, 113(1), 123-148. https://doi.org/10.1007/s11192-017-2484-X 
Parashar, S. (2018). The WPS agenda: A postcolonial critique. In S. E. Davies and J. True (Eds.), The Oxford handbook of women, peace, and security (pp. 1-13). Oxford University Press.

Rayman, P. M., Izen, S., Parker, E. (2016). UNSCR 1325 in the Middle East and North Africa: Women and security. https://www.usip.org/publications/2016/05/unscr-1325-middleeast-andnorth-africa-women-and-security

Saferworld. (2012). National Action Plan 1325 \& 1820: Needs assessment of the monitoring and evaluation of the national action plan on the implementation of the UNSCR 1325 \& 1820. https://www.saferworld.org.uk/resources/publications/676-needs-assessment-of-themonitoring-and-evaluation-of-the-national-action-plan-on-the-implementation-of-the-unscr$1325-1820$

Sapkota, C. (2017). FY 2018 budget overview. https://nepaleconomicforum.org/neftake/fy2018-budget-overview/

Search for Common Ground (2016). Way forward: Implementing the women, peace and security agenda. https://www.sfcg.org/wp-content/uploads/2017/01/001-Consolidated Report_Revised_Final-Draft_20161109.pdf Shepherd, L. J. (2016). Making war safe for women? National action plans and the militarisation of the women, peace and security agenda. International Political Science Review, 37(3), 324-335. https://doi.org/10.1177/0192512116629820

Shrestha, P. M. (2018, August 28). NGO funds outweigh grants to government. Kathmandu Post. http://kathmandupost.ekantipur.com/news/2018-08-28/ngo-funds-outweigh-grants-togovernment.html

Shwaku, N. (2017). Implementing the women, peace and security agenda. Global Affairs, 3(4-5), 455-467. 
Skjelsbaek, I., \& Tryggestad, T. L. (2018). Donor states delivering on WPS: The case of Norway. In S. E. Davies and J. True (Eds.), The Oxford handbook of women, peace, and security (pp. 1-15). Oxford University Press.

Swaine, A. (2009). Assessing the potential of national action plans to advance implementation of United Nations Security Council Resolution 1325. Yearbook of International Humanitarian Law, 12, 403-433. https://www.peacewomen.org/assets/file/Resources/Academic/1325_assessingthepotentialofn aps_aislingswaine_2009.pdf https://doi.org/10.1017/S1389135909000142

Thomson, J. (2018). The women, peace, and security agenda and feminist institutionalism: A research agenda. International Studies Review, 21(4), 598-516. https://doi.org/10.1093/isr/ viy052

Tickner, J. A., \& True, J. (2018). A century of international relations feminism: From World War I women's peace pragmatism to the women, peace and security agenda. International Studies Quarterly, 62(2), 221-233. https://doi.org/10.1093/isq/sqy021

Trial International (2016). Enforced Disappearance, Torture and Alleged Arbitrary Execution of Mr. Gyanendra Tripathi in September 2003. https://trialinternational.org/latestpost/enforceddisappearance-torture-and-alleged-arbitrary-execution-of-mr-gyanendratripathi-in-september-2003/

Trojanowska, B. K., Lee-Koo, K., Johnson, L. (2018). National action plan on women, peace and security: Eight countries in focus.

http://docs.wixstatic.com/ugd/b4aef1_134250725e1b46388140b4ebb409f74a.pdf True, J. (2016). Explaining the global diffusion of the women, peace and security agenda. International Political Science Review, 37(3), 307-323. https://doi.org/10.1177/01925 12116632372 
True, J., \& Hewitt, S. (2018). What works in relief and recovery. In S. E. Davies and J. True (Eds.), The Oxford handbook of women, peace, and security (pp. 1-17). Oxford University Press.

True, J., \& Svedberg, B. (2018). WPS and international financial institutions. In S. E. Davies and J. True (Eds.), The Oxford handbook of women, peace, and security (pp. 1-17). Oxford University Press.

Tryggestad, T. L. (2018). Negotiations at the UN: The case of UN Security Council Resolution 1325 on women, peace and security. In K. Aggestam \& A. Towns (Eds.), Gendering diplomacy and international negotiation. Studies in diplomacy and international relations (pp.239-258). Palgrave Macmillan.

UN Women (2015). Preventing conflict, transforming justice, securing the peace: A global study on the implementation of the United Nations Security Council Resolution 1325. http://wps.unwomen.org/pdf/en/GlobalStudy_EN_Web.pdf UNHCR and UNAIDs. (2016). Joint HIV assessment mission of conflict-affected populations in Nepal. https://www.unhcr.org/uk/47e2422b2.pdf Women's International League for Peace and Freedom. (2017). Member states. http://www. peacewomen.org/member-states

Yadav, P. (2016). Social transformation in post-conflict Nepal: A gender perspective. Routledge.

Yadav, P. (2017a). 1325 - Is that a taxi number? Implementation of the national action plan on 1325 and 1820 in Nepal. LSE Women, Peace, and Security Working Paper Series 4. Yadav, P. (2017b). Can IDP women in the entertainment sector be part of the WPS agenda? http://blogs.lse.ac.uk/wps/2017/09/28/can-idp-women-in-the-entertainment-sector-be-partofthe-wps-agenda/ 
Yadav, P. (2019). Speaking from the ground: Transitional gender justice in Nepal. In L. Fiske \& R. Shackel (Eds.), Rethinking transitional gender justice: Transformative approaches in post-conflict settings (pp. 221-238). Palgrave Macmillan.

Yadav, P. (2020). Can women benefit from war? Women's agency in conflict and postconflict societies. Journal of Peace Research. DOI: 10.1177/0022343320905619

\section{Notes}

' The full text of UNSCR 1325 is available at http://www.un.org/en/ga/search/view_doc. asp?symbol=S/RES/1325(2000).

ii All of the UN Security Council Resolutions on WPS are available at http://www.un.org/en/ peacekeeping/issues/women/wps.shtml.

iii See for details of member states who have adopted their NAPs, https://www.peacewomen. org/member-states.

iv CEDAW General Recommendation 30 is available at https://www.refworld.org/docid/ 5268d2064.html

${ }^{v}$ See https://www.peacewomen.org/member-states

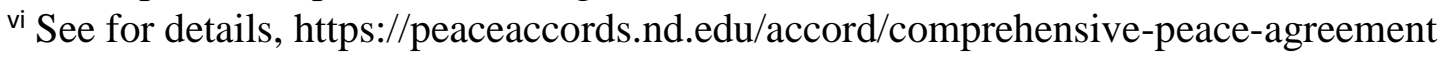

vii The Story Kitchen, a non-governmental organization, has been collecting stories of CRSV for the past five years, see http://thestorykitchen.org/

viii See for more details http://www.ciedp.gov.np/index.php

${ }^{\text {ix }}$ See for more details http://trc.gov.np

${ }^{x}$ For more information on the launch of the NAP on UNSCRs 1325 and 1820, see http:// www.peacewomen.org/content/nepal-nepal-launches-national-action-plan-women peacesecurity- internationally

${ }^{x i}$ See for more details, http://www.nptf.gov.np/content.php?id=259

xii See for more details, http://moha.gov.np/en/member/peace-promotion-section

xiii See for more details, http://portal.mof.gov.np/portal/

xiv See for more details, http://www.swc.org.np/wp-content/uploads/2017/08/ngo_rec.pdf

${ }^{x v}$ See for more details, http://www.swc.org.np/wp-content/uploads/2016/03/INGOsdetailinformation-2072_073-Falgun-Masant.pdf

xvi See the third UK NAP (2018 - 2022) https://assets.publishing.service.gov.uk/government/ 
uploads/system/uploads/attachment_data/file/677586/FCO1215-NAP-Women-PeaceSecurity-ONLINE_V2.pdf

xvii See NPTF progress reports from 2012 to 2016 :

http://www.nptf.gov.np/content.php?id=259 